\title{
ENVIRONMENTAL CUBA VERSUS ECONOMIC TRANSFORMATION
}

\author{
Katarzyna Dembicz¹, Oscar Barboza Lizano² \\ ${ }^{1}$ Center for Latin American Studies \\ University of Warsaw \\ Smyczkowa 14, 02-678 Warsaw: Poland \\ khdembic@uw.edu.pl \\ 2 Faculty of "Artes Liberales" \\ University of Warsaw \\ Nowy Świat 69, 00-046 Warsaw: Poland \\ oscarbarbozalizano@gmail.com
}

\begin{abstract}
The implementation of economic reforms at national and local level by the government of Cuba would have direct and roundabout impacts on the natural environment of the Island. It will also change irreversibly its environment as well as perception of this country as an "environmental paradise ". We will approach the subject based on our observations made during a field study, in 2012 in Cuba. The objective is to discuss the environmental impacts that may be caused by the invigoration of economic activity, together with the liberalization of certain commercial and productive activities on the Island.
\end{abstract}

Key words: Cuba, environmental changes, economic transformation, economic liberty.

\section{Introduction}

Implementation of economic reforms and greater market liberalization have profund positive and negative consequences, both in the social and the environmental sphere. Even more so in a globalised world, ruled by major international institutions such as the IMF and the World Bank (Stiglitz 2006).

Cuba is one of the last countries of the socialist block. Over the next few years it is set to undergo a number of wide-ranging reforms as it becomes further incorporated into global trade and financial systems.

Although the economic reforms, implemented since 2008 by the government of Raúl Castro are limited in scope, their social and environmental repercussions can already be observed. It is the latter problem that is of greatest interest to us. Despite the large and growing number of academic works dedicated to Cuba, only a few comprehensively assess the environmental costs of the growing economic freedom granted to the Cubans. More importantly so, when taking into account the ongoing debate on global warming and the relationship between the man and the environment. 
The objective of this study is to discuss the environmental impacts which may be caused by the invigoration of economic activity, together with the liberalization of certain commercial and productive activities on the Island.

The political system of contemporary Cuba is based on a planned economy in which production decisions and investments are included in the plans formulated by central authorities. This also applies to the natural environment and its protection. Therefore, it is the government actions that will be decisive, in the coming years, for the condition of the environment in Cuba.

In our opinion, current economic transformations taking place in Cuba, at the national and local scale, will have direct and indirect repercussions on it natural and geographic environment. The current analysis is a result of field research carried out within the framework of the project entitled "Quo Vadis Cuba? Implications for Europe and Poland" of the Center for Latin American Studies of the University of Warsaw (CESLA-UW). It is an attempt to touch upon the topic of growing environmental problems in Cuba, in the context of rising economic freedoms of its citizens and of reforms implemented by the government.

We centre our research on observations and in-depth interviews made during our field study. Based on these, as well as on statistics, environmental reports, scientific literature and the state of legislative framework in Cuba, by using methods of comparative analysis, we will try to indicate the major risks for the Cuban environment.

In order to be able to discuss the vulnerability of the natural environment of Cuba, it is necessary to take into account the historical context, in which an important part was played by the economic conditions of the Island in the 19th and the first half of the 20th century. During that time the Cuban soil and underground waters were intensively used for the monoculture of sugar cane and sugar production as well as the cultivation of tobacco and coffee (Mintz 1986).

Critical to this study was fieldwork undertaken in the spring of 2012, when covered 1000 kilometres by bikes, reaching remote sites, away from major tourist and urban locations, and removed from the sight of foreign tourists.

\section{Historical background}

The most famous description, emphasizing the beauty and richness of nature of this Caribbean Archipelago's biggest territory, is attributed to Christopher Columbus, who in 1492 were to say: "es la tierra más hermosa que los ojos humanos hayan visto" ${ }^{1}$ (Dembicz 2006). Despite its landscape beauty and diversity, and the privileged geographical location, until the 18th century Cuba had developed relatively slowly in comparison with the neighbouring Haiti, Jamaica or the more distant Barbados and Martinique. The policy of the Spanish Crown, which was mainly responsible for limiting Cuba's economic growth, led to a situation where after 300 years of colonization, the landscape of many areas in Cuba remained almost untouched by human activity (Guerra 1971).

Following the British occupation of the Island, Cuba experienced economic restructuring and large-scale sugar cane industry development, which later became the basis of the economy and did not remain indifferent to the natural environment (Montaner 2006). Although it lasted only 11 months (from August 1762 to July 1763), it caused deep and permanent changes in Cuban trade, agriculture and society; it also led to a dynamic development of Havana, which opened its gates

1 The most beautiful land human eyes have ever seen. 
for trade with other colonies. During these months, 200 ships docked in Havana, the number was much higher than the annual average for the preceding years which did not surpass 15 . During this period, 5000 slaves were brought to the Island to work on large sugar cane plantations drastically developed by the British. In fact, it turned out that Cuban sugar could compete in terms of price with the Haitian one. As a consequence, after the British signed the treaty in Paris and retreated from Cuba, the Spanish got convinced that the profits from selling sugar could be so high that they yielded to the oligarchy and increased the number of issued permits, allowing the import of slaves.

Political and economic changes initiated during this period opened Cuba to new - other than the Spanish - markets, causing deep transformations in the natural environment. For the following 200 years the Cuban economy was based on agriculture, whose main export was sugar (Bethell 1992).

This situation did not change even after 1959, though some modifications intending to diversify the agricultural production and the land ownership structure were introduced. The revolutionary authorities, like all other previous governments of independent Cuba, treated natural resources as a source of income for the benefit of the development and modernization of the country. The following two citations from Fidel Castro's speeches in 1960 illustrate this stance well:

"But us Cubans need to have a detailed understanding of every grotto and every cave; Cubans need to have knowledge about each and every mountain, every valley, every stream, every feature of the terrain, every tree; that is to say we need to know our nature and identify ourselves with it, because this is our land... Identify the young, identify the nation with its land, ...identify it with its destiny, which is precisely the destiny of a nation that wants to work and that wants to benefit from the scenery and the richness of the land on which it lives. (...)

Cayo Largo was unknown to almost everyone in Cuba; really, we had never heard of its marvellous beaches and ... we went to Cayo Largo, and Cayo Largo is crying out to be one of the most important tourist centres in Cuba.

...we went to the Ciénaga de Zapata, and ... our interest for the Ciénaga de Zapata was awaken; and today, within the space of only a couple of months, the Ciénaga de Zapata is turning not only into one of the most beautiful tourist centres in Cuba, but also into one of the richest regions of the country" (Castro 1960).

At that time, the extractive economic model was characteristic for most of the countries of the Globe, aimed at reaching the highest and the fastest economic growth through the maximum exploitation of natural resources. This type of pattern has been implemented in all of the Caribbean region, regardless of the adopted political model; as mentioned by José M. Mateo Rodríguez: "the Caribbean and Central American societies regarded themselves obliged to intensely exploit the natural resources in order to guarantee the development of their economies..." (Rodríguez 1987: 229). As a result, Cuba and its society have been for decades deprived of durable legislative framework and state institutions, which would oversee the protection of the natural environment of the Island. It was only at the beginning of the 90s that changes were introduced, resulting from the worldwide trend to follow the path of sustainable development.

\section{The legal basis for environmental protection in Cuba}

Following the Revolution and the subsequent waves of emigration between 1959-62 and 1964-73, Cuba experienced a severe decline in intellectual capital. Given the shortage of expertise, the new State (under construction) required almost immediately new professionals, technicians, professors 
and researchers, not only to carry out pending works but also to train new cadres according to the socialist and communist doctrines. In this way, support arrived from the fraternal Eastern European States, which sent their experts and scientists to the Island (Makowski \& Miętkiewska-Brynda 2013). However, in those days environmental sensitivity was rather low, even more so in the countries of the socialist block, characterised by the use of less sophisticated technologies and high power consumption. These countries were founding their economies on heavy industry (metallurgy, shipyards, mining), and did not consider the environment as a priority. This was also the case of Cuba which in addition to being heavily involved in the aforementioned economic activities, was also developing its agricultural sector. The increased cultivation of sugar cane, citrus fruits as well as cattle grazing and dairy production have contributed to the contamination of the environment and degradation of land (Iñiguez \& Rodríguez 1980).

However, the consequences of these economic activities in Cuba did not go any deeper. They were interrupted in the decade of the 1990s by the economic crisis, which arose from the dismantling of the socialist block. The autarchy in which the country found itself, obliged it to diminish the majority of economic activity, also regarding the development of the water supply, sewage and sewerage infrastructure, and the management of solid and liquid wastes.

In comparison with other Caribbean islands, for more than fifty years after the triumph of the Revolution in 1959, Cuba - the largest of the Antilles - took advantage of its natural resources: water and minerals, without a major preoccupation for the future effects of such attitude. This situation is caused by various circumstances:

1. The Cuban archipelago consists of $111785 \mathrm{~km}^{2}$ of mainland, its total population is $11,247,995$ inhabitants with urban population at the level of $75 \%$. Among the Antilles Cuba is viewed as: 'the richest in possibilities due to both its large area and a variety of resources'.

2. Cuba is characterised by a low anthropopression level, 102 people per square kilometre.

3. Economic crises and lack of foreign investment.

In the years following the Revolution, the state tools for fighting the environmental degradation, as well as the social ecological awareness were minimal, not to say nonexistent. This was largely due to the lack of wider laws to protect the natural environment of the island and reduce its contamination.

Cuba's participation in the United Nations Conference on Environment and Development in 1992 encouraged changes in the institutional structure of the country's institutions managing the environment. Following the Conference, the concept of Sustainable Development was integrated into the Article 27 of the Cuban Constitution. In addition, the Ministry of Science, Technology and Environment (CITMA), and the Environment Agency were created. As an example, incorporated into the law were the processes of Environmental Impact Assessment and the granting of Environmental Licences for the development of projects and public works, among others. Pursuant to the Decree 201 of 1999, the National System of Protected Zones of the Republic of Cuba was created (Castro Ruz 1999). As a result, three types of protected areas have been established:

1. of national significance,

2. of local importance,

3. special regions of sustainable development.

In this framework, different types of protected areas were defined: nature reserves, national parks, ecological reserves, natural monuments, reserves of flowers, wildlife reserves, protected landscape parks, and areas of protected resources. 


\section{Economic transformations}

The profound crisis that Cuba declined into in the 1990s, obliged its government to make decisions and to undertake measures to address the problems deriving from this situation. Moreover, added to this were other phenomena such as high emigration rate, low fertility, and a dynamic ageing of the population.

In the course of the last twenty years, especially since 2008 which marked the accession to power of Raúl Castro, Cuba experienced a significant development of the tourist sector, extension of margins for private activity (transportation services, food and catering, small agriculture and livestock production etc.), augmenting foreign investment in the tourist, oil, mining, and sugar sectors, as well as telecommunications industries.

The latest reforms introduced by the Cuban government (migration, foreign investment, fiscal law) and the agreements signed between Cuba and the United States gradually mitigated the effects of embargo resulted in a greater movement of economic factors and people within the area of the Island, exposing regions hitherto untouched or only slightly transformed by humans.

Changes taking place on the Island will have their long and short-term multidimensional, immediate repercussions: social, as well as economic, political and environmental ones, all of them closely interrelated.

The economy will benefit from it the most. The tourist sector registered the arrival of a record number of foreign tourists in 2014, which surpassed 3 million people, and in 2015 surpassed 3.5 million. Numbers comparable to those for the Dominican Republic (ONEI 2015).

The dynamic development of tourism, together with the implemented economic reforms, have created a snowball effect. The tourist sector which in the 1980s was insignificant for the Cuban economy, today enhances development of other areas of economic activity. These are: construction and agriculture, favoured also by the new politics of the United States, which will allow the export of materials for construction and agricultural sectors as well as goods for the development of selfemployment activity. The Cuban agriculture already possesses certain support tools, such as trade of inputs, increase sales prices of products imposed by the State, credit lines, wholesale market for non-state products. All the above mentioned factors will foster the creation of new jobs, especially in the private sector (Dembicz 2015).

The increased credibility of Cuba awakened international interest for other areas of its economy in need of modernization, capital and technology. These are: the energy sector, the mining industry, the metallurgy and the petrochemistry, as well as national and international transport - aerial, water and land. Today renovation plans are being developed for the Puerto de Mariél, which will play the role of a megaport and will easily compete with the Hub ports of Florida, the Bahamas, Kingston or San Juan. Brazil as a significant Latin American partner (in addition to the Mariél port) is investing in the renovation of sugar production plants. There are also plans for rapid development of the railway network.

However, in order to carry all the aforementioned activities out, a big power supply will be needed, but unfortunately Cuba does not possess it today. It will be a major challenge to create, in a very short space of time, conditions for the increase in electricity production, which implies the use of verified and cheap technologies. According to press information, investments will be made in the development of thermal power plants, largely contaminative for the natural environment (Nuevo Herald 2015; RT 2015). 
The favourable international and economic situation which Cuba is currently in, will have repercussions for the environment. Therefore, a question needs to be asked: what are the elements most exposed to changes today, given this intense and aggressive economic activity? We will try to answer this question in the following paragraphs.

\section{The vulnerability of some of the elements of insular environment}

The dynamism of economic activity within the insular space of Cuba, resulting from the improved relations between Cuba and the rest of the world, threatens its natural environment, which can be defined as highly vulnerable due to the lack of experience of Cuba and its inhabitants in protecting and generally dealing with the environment based on the sustainable development approach.

In this study, we shall focus on the analysis of the three principal elements of the environment: soil, water and air. The good condition of these three elements is of key importance for the quality of life of the inhabitants of the Island, including their health and nutrition, as well as for the development of agricultural sector and industrial production. The interdependence of these factors is very strong, as they are exposed to the influence of both anthropogenic and natural determinants. Hurricanes, heavy rains and draughts may be both causes and effects, changing the characteristics of each of these elements, same as human activity, especially in the agriculture and livestock sector, tourism, and industry.

Below we made a brief presentation of the condition of Cuban natural environment is currently in.

\section{Coastal, ground and surface waters}

Cuba's geological structure, land relief and climate all have an impact on its hydrological and hydrogeological features. The watershed line runs along the island, dividing its territory between two drainage basins: the Caribbean Sea and the Atlantic Ocean (Iñiguez \& Rodríguez 1980). Cuban rivers mainly flow from south to north or from north to south, with some exceptions, including Cauto and Cuyaguateje, flowing from east to west, and the river Toa, which flows from west to east. There are 900 rivers in $\mathrm{Cuba}^{2}$, including 536 big ones - flowing into the sea. 236 meet their estuary in the north and 237 in the south (Iñiguez \& Rodríguez 1980).

For an insular country, which is deprived of the possibility to utilise its direct neighbours' water resources, its own water supplies are of prime importance for the economy and the survival of the people. They are also an essential means of monitoring the condition of natural environment.

In the case of ground water supplies, the main points of exploitation are in Havana. In 1976, $77 \%$ of water consumed by the inhabitants in the Island came from ground water sources (Iñiguez \& Rodríguez 1980). The eastern part of the Island displays the highest deficits of water; this was the case in the past and it has not changed until today. Agriculture was the biggest consumer of water, mainly for irrigation purposes. In the 1970s, almost 289 settlements in Cuba were connected by water pipelines and Havana accounted for $95 \%$ of the total ground water consumption (Iñiguez \& Rodríguez 1980). Currently, the Havana province is also characterised by the highest water consumption.

In 1976, sewage was the main cause of contamination of the Island. Data from this period demonstrate that waste came primarily from households $-68 \%$, industry $-23 \%$, and cattle farming

2 including temporary rivers. 
- 9\% (Iñiguez \& Rodríguez 1980). Scientists researching this aspect point out that the situation was made worse by the lack of an organised sewage disposal system. Sewage was discharged into the rivers flowing through the cities, ending in the seas. Because of that, these rivers are usually short, with a low water level, their capacity for self-cleaning is severly limited, which increases the risk of serious contamination of sea and coastal waters (Chobalina \& Beltrán 2002). In fact, this situation has not evolved. Today (2014), there are only 10 sewage treatment plants in Cuba (ONEI 2015). Although sanitation is guaranteed by a public sewer system (to which more than 4.03 million people are connected) the domestic evacuation through tanks and latrines is still very common (this device is used by more than 6.7 million people). Consequently, out of 900 rivers crossing the Cuban territory, currently about 250 are on the verge of an ecological disaster. This is caused by sewage from households and post-production waste, rich in organic and chemical elements, as well as heavy metals.

For centuries, Cuba experienced rapid agricultural development, which contributed to the excessive exploitation of natural resources, due to the establishment of extensive latifundia. These large-scale plantations produced coffee, sugar cane and tobacco. They possessed a developed system of irrigation channels and favoured many types of shifting crops, the so-called cultivos itinerantes, for which forests were burnt and cut down. ${ }^{3}$ Excessive exploitation of forests, together with an accelerated soil depletion between 1940-1960 also had an impact on the renewability and storage of both surface and ground waters (Rodríguez 1987). Soil erosion caused by flowing rivers, which collected harmful, sediment substances from the fields, contributed to the inhibition of proper flow of surface waters.

At the beginning of the second decade of the 21st century, Cuba possesses a high level of water supplies intended for consumption per capita, but at the same time, because of the lack of sufficient investments in water distribution infrastructure, there is often a shortage of water. At this stage, special attention should be paid to the situations endangering public health, such as the outbreaks of cholera epidemics experienced by the Cuban provinces of Granma and Santiago de Cuba between 2011-2013. In July 2012, 158 cases of cholera virus infections and three mortalities were recorded (Cubadebate 2012).

The largest water supplies per capita can be found in the central regions of Cuba - about 2,716 $\mathrm{m}^{3}$ per inhabitant per year ${ }^{4}$, especially in the province of Sancti Spiritus, followed by the province of Matanzas, Pinar del Río, and Mayabeque - between 2,027 and 2,291 $\mathrm{m}^{3}$ per inhabitant per year. In the case of Havana, the largest population cluster and the primary consumer of water, these resources amount to the mere $149 \mathrm{~m}^{3}$ per inhabitant per year. ${ }^{5}$

Based on the Water Resources Institute data for 2011, it was estimated that water extraction should come to 7,167 billion $\mathrm{m}^{3}$, including 1,657 billion $\mathrm{m}^{3}$ for industry and 3,892 billion $\mathrm{m}^{3}$ for agriculture, forestry and fisheries.

\footnotetext{
3 Among the causes of this was also charcoal production. The profession of a coalman, Spanish - carbonero, has remained popular in Cuba to this day.

4 Cubic meters calculated per inhabitant per year.

5 By way of illustration, in 2010 the average available water supply per capita in Poland amounted to almost 1,400 $\mathrm{m}^{3}$ /inhabitant/year (data taken from KZGW “Diagnoza aktualnego stanu gospodarki wodnej", http://kzgw.gov.pl/files/file/ Programy/PPWP2030/Zalaczniki_do_projektu_Polityki_wodnej_panstwa_do_roku_2030.pdf)
} 


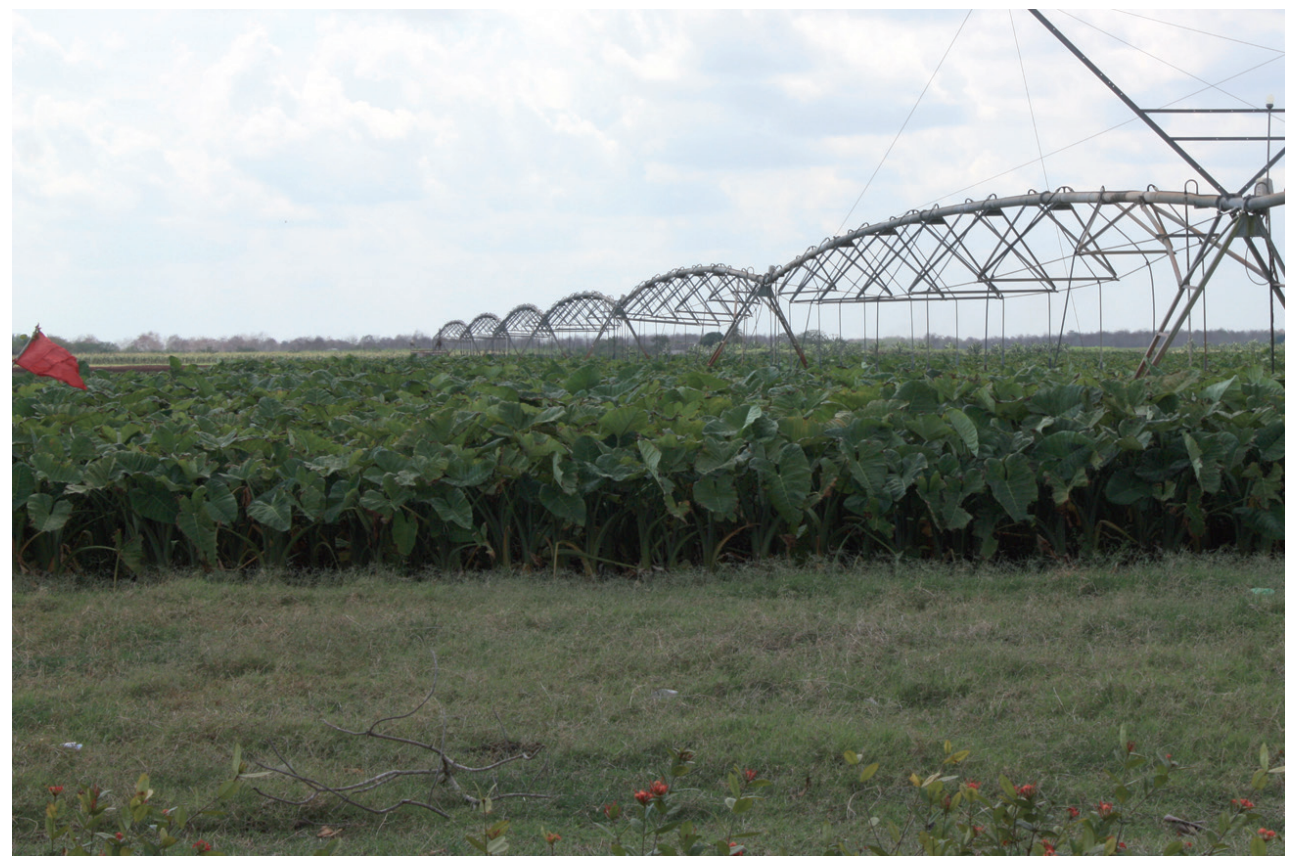

Figure 1. Irrigated fields in the province of Pinar del Rio (by: W. Doroszewicz, 2012)

The remaining supply of water is allocated for other economic activity, including tourist services and private households. Currently, the largest volume of water (over 60\%) comes from surface water - an average of 4,405 billion $\mathrm{m}^{3}$; the rest originates from the underground sources and is estimated at 2,376 billion $\mathrm{m}^{3}$. The volume of freshwater, which returns unused, is estimated at 387 million $\mathrm{m}^{3}$ (ONEI, 2015). In the 1960s and 1970s, an average of 4 billion $\mathrm{m}^{3}$ was consumed, mainly coming from underground sources, whose total supply was estimated at 6,5 billion $\mathrm{m}^{3}$ (Iñiguez \& Rodríguez 1980).

As mentioned above, a considerable change in the structure of water consumption can be noticed, including a decline in the importance of underground waters for the economy of the Island. Since the beginning of the 21st century, surface waters have seen a significant increase in exploitation - in comparison to 1960 s and 1970 s - their average use is higher by 3 billion $\mathrm{m}^{3}$. This was possible, i.a., thanks to the construction of retention storage reservoirs, which contribute to mitigating water shortages during the periods of draughts. However, given the increasing number of draughts, such reservoirs are insufficient. Currently, 239 such reservoirs exist on the Island ${ }^{6}$. During one of the most severe draughts (2003-2005), as many as 114 of them disposed of $25 \%$ of their water capacity. The losses caused by this natural disaster reached 1 billion dollars (Jiménez \& Galizia 2014).

During the last two decades, the structure of water supplies utilisation in Cuba has not been altered. Still most of the water is consumed by the primary sector, namely agriculture, livestock farming, forestry, and fishing, followed by households and industry.

Currently, $94 \%$ of Cuba's population has access to potable water and $96 \%$ uses the network of sanitary sewers; however, the country's territory is not evenly covered by the sewage system. In

6 Before 1959 there were only 13 of these Project, with the capacity of $48 \mathrm{mln} \mathrm{m}^{3}$. 
the central region, especially in the provinces of Cienfuegos and Villa Clara, access to running water is low and varies between 64 and $83 \%$, while in the provinces of Sancti Spiritus and Camagüey the percentage of people with access to running water is very high -98-99\%. For sanitary sewage, the lowest values are recorded in the provinces of Sancti Spiritus and Camagüey, but they still should be considered as high, as they oscillate between $95-97 \%$. In the east of the Island, provinces with a limited coverage of the water supply system include Granma and Santiago de Cuba $-64 \%$, while in Las Tunas, Holguín and Guantánamo the corresponding figures are relatively high, reaching $90 \%$ and $83 \%$ respectively.

The dynamic development of hotel construction, accompanied by the boom for single-family homes, may create high anthropopression in certain areas, which will require potable water to be transported from more distant locations. At the same time, this activity will cause deterioration of surface and coastal waters. The latter will probably receive special treatment, given that they form part of a wide variety of tourist attractions used in the creation of the national branding.

Given the need to preserve an idyllic image of the Island in order to uphold the level of attraction of Cuba as a tourist destination, the Cuban government is adapting measures to preserve certain areas, strategic for tourism, in good environmental condition. Such is the case, for example, with the Almendares river, which crosses the city of Havana and which continued to deteriorate for decades due to the industrial activity, such as the discharge of waste water from the city, terminating in the sea (Chiroles Rubalcaba et al. 2007). The current sanitary levels of the Almendares river are expected to improve thanks to the introduction of the Gran Parque Metropolitano de La Habana (GPMH) programme, an environmental initiative of the government.

\section{The soil}

According to the information made available by the Oficina Nacional de Estadistica e Información (ONEI), out of the entire Cuban territory - that is 10,675 million hectares $-60 \%$ is used for agricultural production, but a part of it (over a million hectares) is covered by untilled lands. This is mainly caused by some unfavourable processes, such as soil erosion, inefficient drainage, low fertility of soils, their rather high level of acidity or salinity, a very small amount of organic matter and low humidity retention. The autarchy in which Cuba remained between 1990 and 1995 led directly to this condition, due to the fact that in result of a deep economic crisis many sugar cane and citrus fruits plantations as well as other agricultural activities were closed down ( $50 \%$ of sugar refineries together with the surrounding plantations) and the State failed to introduce any alternative economic proposal. Areas formerly used for sugar cane monoculture are nowadays still largely overgrown by invasive plants, such as marabú (Dichrostachys cinerea).

Within the framework of the National Soil Protection and Improvement Programme (Programa Nacional de Mejoramiento y Conservación de Suelos), implemented in 2005, an amelioration was observed in areas covered by the programme. Specal repair programmes were implemented on almost 700 thousand hectares of land, which at the same time were covered by special protection. According to the of ONEI data, gathered based on the National Register of the Cuban Geography and Geodesy Office (Catastro Nacional de la Oficina de Geografía y Geodesia), around 6.3 million hectares are used in agricultural activity annually, including 3,990 thousand hectares for the cultivation of perennial plants and 1,187 thousand hectares for the cultivation of annual plants. Moreover, an improvement in recovering untilled and abandoned land was observed after the implementation of reforms by Raúl Castro -thanks to which farmers may now lease (for the period of 10 years) 
state-owned lands, apply for loans for the purchase of seeds and fertilizers, and sell their products directly to the private recipients - both hotels and individuals.

The areas covered by forests are of prime importance for the good functioning of the ecosystem and water circulation. Both the natural forest and planted forest areas occupy the surface of $3,178,800$ hectares, representing $29 \%$ of the total Cuban territory. Between 2008 and 2014, the forested area grew by $6 \%$. Natural forests take up $83 \%$ of the entire wooded area. The province most densely covered by forests is Camagüey, where woods cover 385,700 hectares, amounting to $26 \%$ of its territory. Fewest forests can be found in Havana. A proportionally biggest number of wooded territories is located in the province of Isla de la Juventud - 63.4\% (ONEI 2015).

The increase of forest-covered area has a positive impact on the water resources and at the same time it helps to counteract soil erosion - a significant problem for many Caribbean islands. Forest plantations are one of the elements of this process; however, in the case of Cuba they are intended exclusively for economic aims - acquiring material for the production of cellulose and wood. According to the publication entitled Panorama Ambiental 2014 (ONEI 2015), around 48 thousand hectares of land are used for this purpose in Cuba. The largest clusters are located in the province of Holguín - 5,640 ha, followed by Santiago de Cuba - 5,450 ha, and Pinar del Río - 5,015 ha. It should be noted that forest-covered area is increasing, to match the growing needs of the Cuban economy.

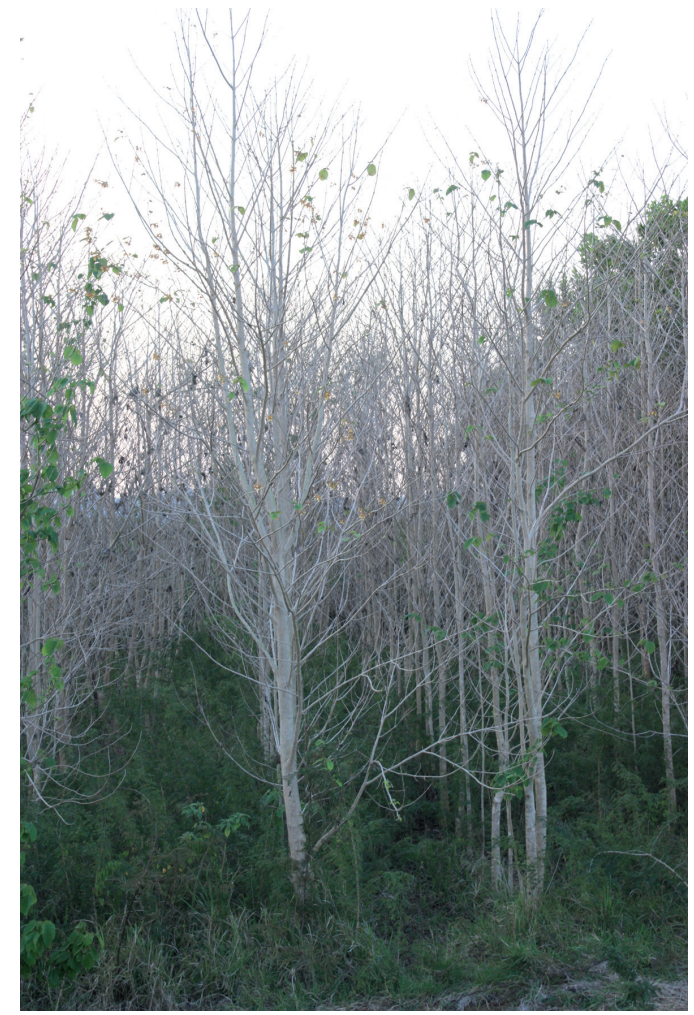

Figure 2. Forest plantation in the province of Pinar del Rio (by: W. Doroszewicz, 2012)

Plots of farmable land in the cities or on their outskirts play a very important part in the Cuban economy. The need to feed the urban population of Cuba $(75 \%$ of the total inhabitants of the 
Island) during the period of the deepest crisis, i.e. the 1990s, led to the maximum utilisation of the unoccupied spaces in the cities for the cultivation of vegetables and fruit. In this manner Cuba became the pioneer in urban organic gardens (organopónicos).

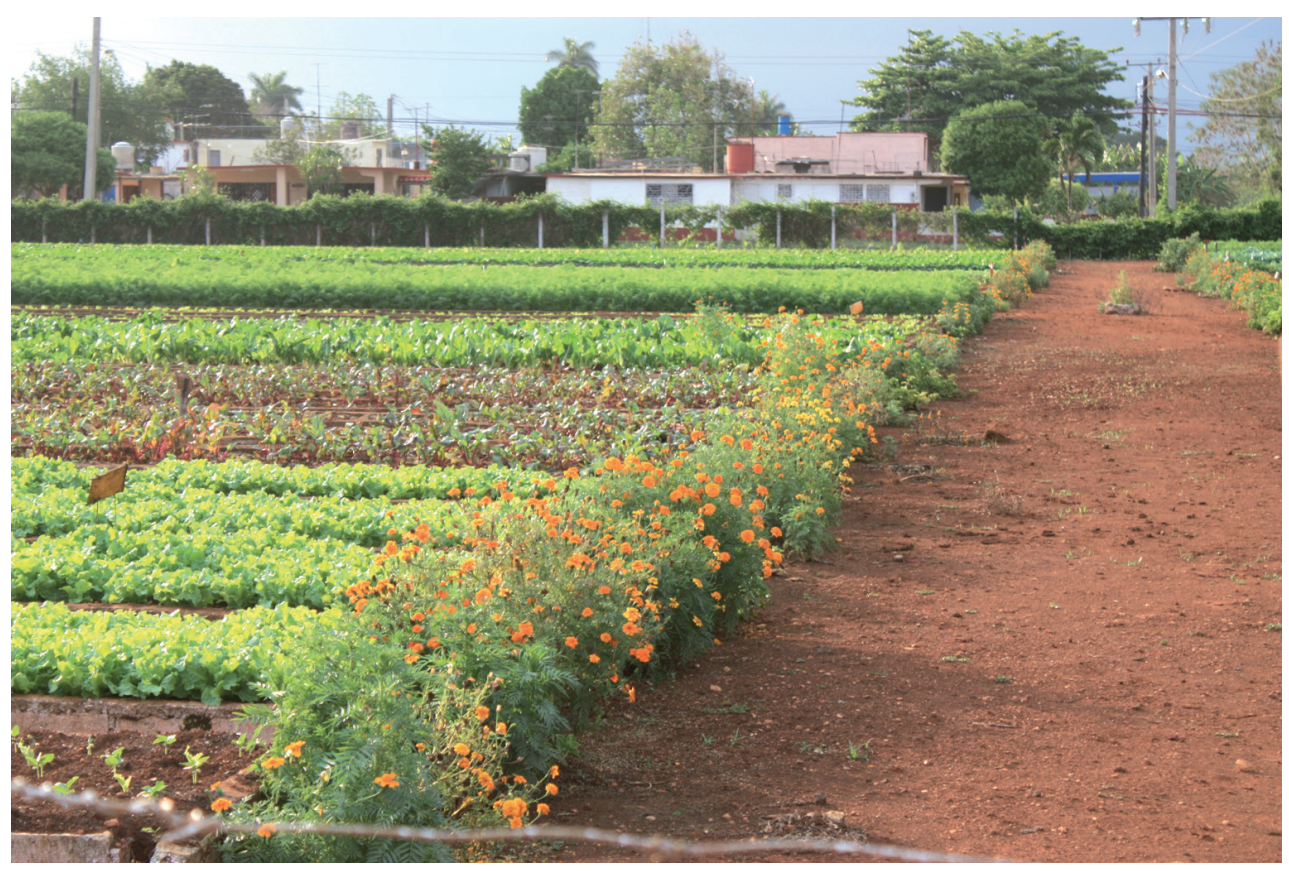

Figure 3. Organopónicos Jaguey Grande (author: W. Doroszewicz, 2012)

Unfortunately, alongside such innovative enterprises, Cuban authorities and Cuban society are unable to deal with waste disposal. Apart from the liquid residues mentioned above, solid waste is also a threat, both for the waters and the lands, as it changes the chemical composition of the soil as well as the landscape of the Island. It also affects the air quality. 


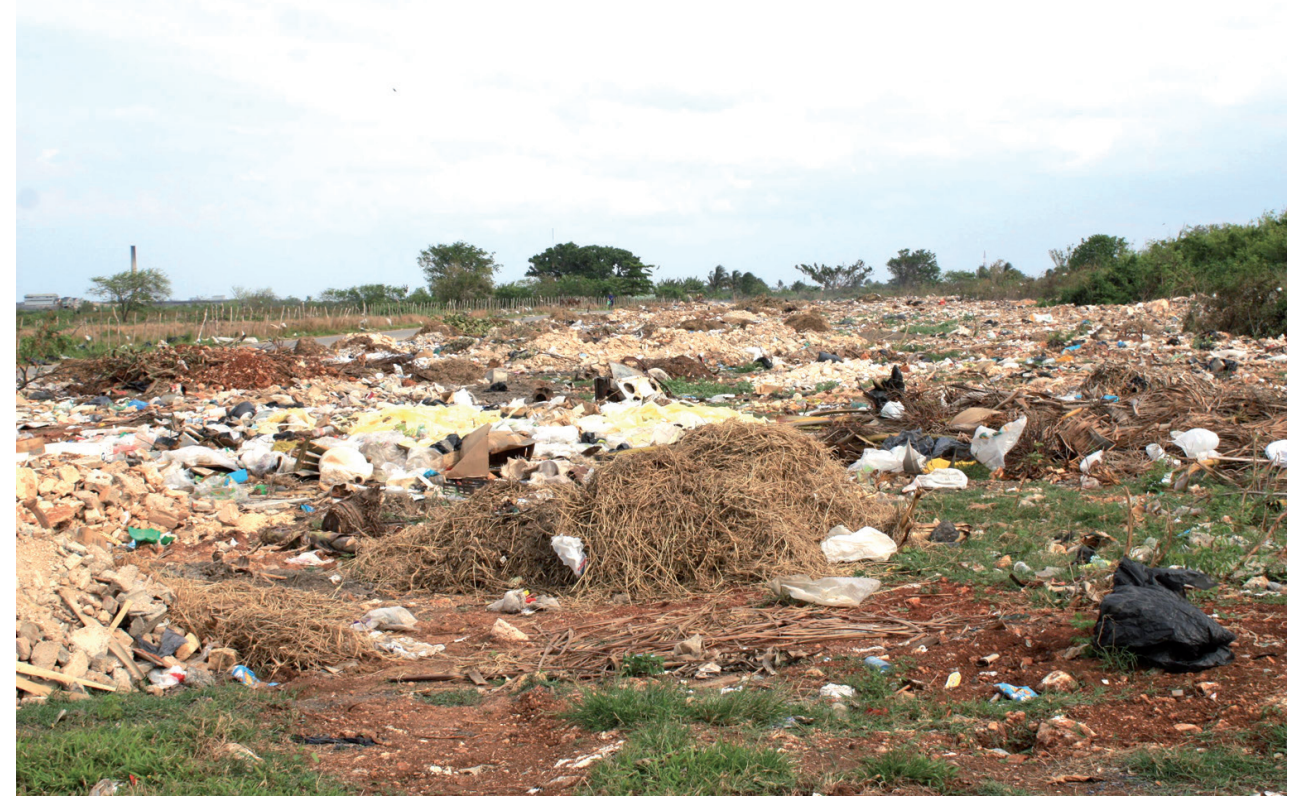

Figure 4. Landfill site between Cárdenas and Varadero (by: O.Barboza, 2012)

\section{The air}

Data from the National Statistics Office confirm that each year over $30 \%$ of Cuban people suffer from respiratory diseases and other conditions related to air pollution, both in indoor and outdoor environments (Calzadilla 2013).

Key factors affecting the quality of air in Cuba include:

- Energy production, which in over $90 \%$ comes from highly contaminative fossil sources; however, it is anticipated that by 2030 the use of renewable sources would grow (reaching up to $30 \%$, but with a high share of bio fuels - derived from sugar cane),

- Industrial processes,

- Use of solvents and other products,

- Agriculture,

- Waste.

For example, industry relies on building structures with low chimneys and it lacks any control mechanisms to reduce the decomposed air, causing increase in contamination. Also the inappropriate practices of the farming sector contribute to air pollution, by generating high levels of contaminants potentially harmful for human health, for ecosystems and for natural resources. Pollutants affecting health of individuals include: sulphur dioxide, nitrogen oxides, unburned hydrocarbons, ozone and other photochemical oxidants.

Also the production of charcoal is worth mentioning, an activity with long traditions on the Island, recently revived due to the need to supply the households as well as local food industry. Its production and use significantly impacts the quality of air, in particular when carcoal is the only energy source able to meet the demand of local society. 
The air quality (especially in Cuban cities) is also threatened by the large increase in the number of motor vehicles in circulation. Today, Cuba lacks an efficient railway network which would interconnect the insular cities, as well as an efficient public transport system in the urban centres. This fact, under the conditions of a dynamic economic growth, may provoke a considerable increase in the number of vehicles for individual use, which in turn will undoubtedly turn into an element polluting the environment. The negative effects that increased traffic will have on the air quality becomes evident when we consider the technological backwardness of the majority of motor vehicles in use. However, these old cars are one of the elements which make the Island so attractive for tourists.

As we can deduce, areas most exposed to the risk the air quality degradation are urban zones. According to the results recorded by the monitoring stations, the cities of Havana, Matanzas, Moa, Nuevitas and Mariel suffered the greatest damage (Díaz Veliz \& Díaz Machado 1999). The urban population exceeds $75 \%$ of the inhabitants of the Island, so air pollution becomes a serious national problem in the context of the dynamic development of the industrial sector in the last decade, especially the most polluting oil and thermoelectric sectors. In 1970, an air quality monitoring system in Cuba was established, led by the Ministry of Public Health, gathering data from various sampling stations in Havana and other provinces. In 2004, the Norm NC: 111 on Air Quality and Rules for monitoring air quality in human settlements was introduced.

Deteriorating air quality in Cuba is due to highly toxic carcinogenic pollutants such as smoke, poly-aromatic hydrocarbons and dioxins. Dioxins are part of persist organic pollutants (POPs). These substances remain present in the environment for a very long period of time. Bioaccumulations also have a harmful effect on humans through the food chain (Schlatter 2007).

Experts have recognized the problems and there are plans to improve the situation. The Cuban government uses European experiences - French and Swiss - in this area to combat the air degradation. As an example, an agreement was signed between a French company Environment SA, dealing with construction and production of air pollution measurement equipment and the Institute of Meteorology of Cuba (Rebelde 2016).

\section{Conclusions}

Since the beginning of the 1990s, Cuba has made an effort to incorporate the environmental policy into its idea of a State. However, it was only during the last decade that significant investments in natural environment protection and revitalisation were achieved. These actions are reflected, for example, in the urge to create protected areas, whose number is increasing year by year. In 1999, only two protected zones existed on the Island - with a total area of $13.5 \mathrm{~km}^{2}$ - and in 2013, there were 103 such zones - exceeding 29 thousand $\mathrm{km}^{2}$ (ONEI 2013).

During the last decade, the value of investments allocated for protection of the environment grew by $2.3 \%$. In 2011, this level attained $10.4 \%$ of the total investments. The largest investments for natural environment protection, counted in millions of pesos CUP, were allocated for the protection of water resources. This sum reached 309 million pesos CUP7. Forestry resources came second with 74 million pesos CUP allocated for their protection ${ }^{8}$. Next in line, was a sum devoted to different

7 Equivalent of $10,050,500$ euros, according to the Cuban internal currency exchange rate; the budget elaborated by the Cuban authorities for 2011 was of 1594 bln euros.

8 Equivalent of $2,406,890$ euros, according to the Cuban internal currency exchange rate. 
activities in this field, equal to 26 million pesos CUP9. In 2011, a total of 452.5 million Cuban pesos was spent on the protection of the environment; $50.8 \%$ of this amount was granted for the protection of hydrological network of national importance, and $3 \%$ for the revitalisation and protection of sea gulfs.

One conclusion which may be drawn from these actions asserts that the main aim of ruling authorities is to improve the water balance of the country and to provide its society, as well as economy, with water. Unfortunately, investments in air quality improvement are declining and those in solid wastes disposal remain at an unchanged level, despite the growing needs and increasingly visible negative changes in the landscape. A similar situation can be observed as far as investments in soil quality improvement are concerned.

In our opinion, the changes implemented in order to stimulate growth of the Cuban economy are a major threat for the natural environment as a whole, as well as for all individual biocenoses. This fact should draw attention not only of the Cuban government, but also of the entire world, which is pressurising Cuba to accelerate the pace of its economy's development, but not offering any technological, economic or logistic measures that would help to protect and preserve Cuba's natural environment in all of its aspects, still before the complete opening up of the Cuban economy.

During the last couple of decades, in result of a deep economic crisis, the environment in Cuba was not as exposed to degradation as was the case in other parts of the world. Within the framework of environmental policy, the ecological stability attained on the Island was undoubtedly the effect of an economic model in which consumption of products generating solid wastes, unsuitable for processing and augmenting the level of contamination, was relatively small. Moreover, until that point Cuba's particular economic situation resulted in the growth, much less dynamic than in other coutries worldwide, of the number of vehicles with a combustion engine using traditional fuels, hence not as much greenhouse gases - harmful for the ozone layer - were released to the atmosphere.

In the context of the current economic and social transformation on the Island, this situation will definitely remain unaltered. Economic changes happening in Cuba, in our opinion, pose a major threat for the natural environment and its protection, and in consequence will deteriorate the quality of life of the Cubans. For example, in locations with a developed tourist infrastructure and where the economy is growing more dynamically, one can observe landfill sites (also illegal ones) deprived of any form of treatment of solid wastes (as seen on the photograph above). Indeed, a fact confirmed by the ONEI analyses, landfill sites in Cuba are situated outdoors, forming not only an unsightly element of the landscape, but also a threat to public health, soils, waters and animals (especially the endemic ones).

The Cuban state, while undertaking measures aiming to revive the economy on the micro scale, should take care of the wastes problem, growing together with the a more dynamic economic activity. The harmful effect of polymers on the environment, produced in large quantities as a result of individual consumption, is commonly known. Therefore, what seems necessary is the establishment of projects including landfill sites, where materials for repeated utilisation and recycling will be segregated efficiently, and the remaining waste will be secured appropriately. Equally indispensible is a more efficient system of rubbish collection.

Another aspect of the environmental policy which should be strengthened is the protection of forestry resources. Forest plantations located in Cuba seem to be insufficient in view of the new dynamic, characterising investments and construction. Taking the historical conditions into account, there exists a high risk of a negative influence of these changes on the environment, especially in

9 Equivalent of 841,193 euros, according to the Cuban internal currency exchange rate. 
the surroundings of ports and in special economic zones. Shipbuilding, including trading vessels, will imply the restoration of Cuba's status as an important centre of transport and commerce. On the other hand, it entails a potential threat for the biodiversity of the island, easy to be disturbed and which today boasts an ecological stability by virtue of a rather small, or non-existent port traffic. Today, the fact that mainly small fishing boats are used in the Cuban fishing industry significantly reduces, or even eliminates, the risk of petroleum derived substances leaking into the sea in the vicinity of protected zones.

Finally, we would like to point out that in the second decade of the 21st century Cuba, and the changes occurring on its territory, are the subject of researche and observation, as a field for the employment of various theories associated with new models of economic development. This case should once again remind the entire humanity that economic issues should never overshadow the issues related to the preservation of the natural environment, to the protection and appropriate utilisation of natural resources, as well as to the protection of species in different biocenoses, which serve to maintain a harmonic synergy on our planet.

\section{References}

Alarcón Quesada R., 1997. Gaceta oficial de la República de Cuba Edición extraordinaria 11 de julio de 1997, año XCV, no. 7, p. 47

Aruca Alois A., 2012. Herramienta para apoyar la transformación del modelo de gestión energética municipal en Cuba, http://www.cubasolar.cu/biblioteca/Ecosolar/Ecosolar24/HTML/ articulo02. htm [7 January 2015].

Bethell L. (ed.), 1992. Historia de América Latina. vol. III, Barcelona: Cambridge University Press/ Editorial Crítica.

Calzadilla Rodríguez I., 2013. Cuba enfrenta la contaminación ambiental' Isla al Sur. Blog, http:// islalsur.blogia.com/2013/072704-cuba-enfrenta-la-contaminacion-ambiental.php [10 October 2015].

Castillo Carpio R., 1961. Triángulo geopolítico del Caribe. Caracas: Imprenta Nacional, 223 pp.

Castro Ruz F., 1999. Del Decreto Ley no 201. Sistema de Áreas Protegidas. Centro de Inspección y Control Ambiental.

Castro Ruz F., 1960. Discurso pronunciado por el Comandante Fidel Castro Ruz, Primer Ministro del Gobierno Revolucionario, en el acto celebrado por la Sociedad Espeleológica de Cuba, en la Academia de Ciencias, el 15 de Enero de 1960, http://www.cuba.cu/gobierno/discursos/1960/ esp/f150160e.html [10 October 2015].

Chabalina L., Beltrán J., 2002. Contaminación marina en bahías y zonas costeras de Cuba y del Gran Caribe. Memorias de VIII Taller de la Cátedra de Medio Ambiente, Vol. I., CD. La Habana: Instituto Superior de Ciencia y Tecnología Nucleares. Ministerio de Ciencia Tecnología y Medio Ambiente. Chiroles Rubalcaba S., et al., 2007. Bacterias indicadoras de contaminación fecal en aguas del río Almendares (Cuba). Higiene y Sanidad Ambiental, no. 7, pp. 222-227, http://www.salud-publica. es/secciones/revista/revistaspdf/bc51015c5d937c3_Hig.Sanid.Ambient.7.222-227(2007).pdf [10 October 2015].

Constitución de la República de Cuba. http://www.cuba.cu/gobierno/cuba.htm [7 March 2015]. 
Cubadebate, 2012. Continúa Combate contra el Brote de Cólera en Manzanillo, No hay mas fallecidos. Cubadebate, 14 julio 2012, http://www.cubadebate.cu/noticias/2012/07/14/continua-combatecontra-brote-de-colera-en-manzanillo-no-hay-nuevos-fallecidos/ [20 February 2013].

Dembicz A., 2006. Filozofia poznawania Ameryki. Warszawa: CESLA UW, 460 pp.

Dembicz K., 2015. Incertidumbres del porvenir de los cubanos. Notes Internacionals, no. 111, doi:10.13140/2.1.1788.6241

Díaz Véliz R., Díaz Machado A., 1999. La calidad del aire en Cuba. Resumed no. 12(3), pp. 151-156 http://www.bvsde.paho.org/bvsci/e/fulltext/2encuent/cuba2.pdf [20 December 2015].

El Nuevo Heral, 2015. Rusia dará crédito de \$1,360 millones. El Nuevo Herald, 20.10.2015, http://www. elnuevoherald.com/noticias/mundo/america-latina/cuba-es/article40559457.html [10 November 2015].

Guerra R., 1971. Manual de Historia de Cuba, desde su descubrimiento hasta 1868, La Habana: Editorial de Ciencias Sociales, $701 \mathrm{pp}$.

Iñiguez Rojas L., Rodríguez Mateo J., 1980. Geografía Física de Cuba componentes Naturales y Paisajes Geográficos. La Habana: Ministerio de Educación Superior de La Habana, 251 pp.

Jiménez Cisneros B., Galizia Tundisi J. (ed.), 2014. Diagnostíco del agua en las Américas. México: IANAS / Foro Consultivo Científico y Tecnológico, 43 pp.

Juventud Rebelde, 2016. Cuba y Francia suscriben acuerdo para monitorear calidad del aire. Juventud Rebelde 2.02.2016, http://www.juventudrebelde.cu/internacionales/2016-02-02/cuba-y-franciasuscriben-acuerdo-para-monitorear-calidad-del-aire/ [2 January 2016].

Makowski J., Miętkiewska-Brunda J., 2013. Zwiqzzki akademickie i naukowe między Polskq a Kubq. Doświadczenia istan obecny' [in:] K. Dembicz (ed.), Relacje Polska-Kuba. Historia i Współczesność, Warszawa: CESLA, pp. 207-218.

Mintz S., 1986. Sweetness and Power. The place of Sugar in Modern History. USA: Pengyin Books, $274 \mathrm{pp}$.

Montaner C., 2006. Los cubanos. Historia de Cuba en una lección. Brickell Communication Group Inc., $192 \mathrm{pp}$.

ONEI - Oficina Nacional de Estadística e Información, 2013. Areas protegidas, www.one.cu [1 February 2015].

ONEI - Oficina Nacional de Estadística e Información, 2015. Anuario Estadístico de Cuba 2014, La Habana: ONEI http://www.one.cu/ [10 October 2015].

Rodríguez Mateo J., 1987. Asimilación agrícola y degradación del medio natural en las montañas de la Sierra Maestra / Cuba. Actas Latinoamericanas de Varsovia Tomo 4.

RT, 2015. Rusia concede a Cuba crédito por 1.200 millones de euros para la construcción de termoeléctricas, Russia Today 10.10.2015, https://actualidad.rt.com/actualidad/189081-rusiaconcede-cuba-credito-millones-central-termoelectrica [10 November 2015].

Schlatter S., 2007. El aire de la Habana, Email discussion lists for the UK Education and Research communities, https://www.jiscmail.ac.uk/ [10 November 2015].

Stiglitz J., 2006. Globalizacja. Warszawa: Wydawnictwo Naukowe PWN, 232 pp.

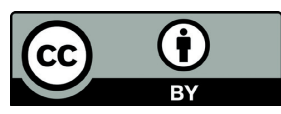

